\title{
Effect of Thymus zygis subsp. gracilis (Boiss.)'s Essential Oil Composition on Human-Pathogenic Bacteria
}

\author{
${ }^{1,2}$ Ali Cherrat, ${ }^{1,2}$ Kamal Fadili, ${ }^{1,2}$ Smail Amalich, ${ }^{1,2}$ Mohamed Regragui, ${ }^{3}$ Mohamed El Amrani, 1,2 Mohamed \\ Bourkhoudar, 1,2 Touriya Zair
}

${ }^{1}$ Research team of Bioactive Molecules Chemistry and Environment, Faculty of Sciences, B.P 11201 Zitoune, Moulay Ismail University, Meknes, Morocco. ${ }^{2}$ Laboratory of Materials Chemistry and Biotechnology of Natural Products, Faculty of Sciences, B.P 11201 Zitoune, Moulay Ismail University, Meknes, Morocco.

${ }^{3}$ Food Units of Technology and Biochemistry, National school of Agriculture, BPS/40, Meknes, Morocco

Correspondence Author: Kamal Fadili, Research team of Bioactive Molecules Chemistry and Environment, Faculty of Sciences, B.P 11201 Zitoune, Moulay Ismail University, Meknes, Morocco.

Received date: 19 April 2018, Accepted date: 15 July 2018, Online, Online date: 31 July 2018

Copyright: (C) 2018 Kamal Fadili, et al. This is an open-access article distributed under the terms of the Creative Commons Attribution License, which permits unrestricted use, distribution, and reproduction in any medium, provided the original author and source are credited.

\begin{abstract}
Aromatic and medicinal plants produce highly odorous molecules that can be extracted as essential oils. These essential oils, because of the chemical nature of their constituents, are considered to be great candidates to help remedy the problem of antibiotic-resistant microorganisms. Thus, essential oils are nowadays tested by several laboratories in order to successfully replace antibiotics. Therefore, our work consists in evaluating the antibacterial activity of Thymus zygis's essential oil against four pathogenic bacteria frequently involved in human infections: Klebsiella pneumoniae, Staphylococcus aureus, Pseudomonas aeruginosa, wild-type Escherichia coli and penicillinase-producing Escherichia coli. Essential oil was extracted by hydrodistillation and analyzed by gas chromatography coupled with mass spectrometry (GC / MS). Then, antibacterial activity was conducted using first the disk-diffusion method on agar medium and after by the macrodilution technique in liquid medium to determine the minimum inhibitory concentrations (MIC) and the minimum bactericidal concentrations (MBC) of Thymus zygis's essential oil. The chemical analyses revealed 95 constituents in this essential oil with Carvacrol $(30.54 \%), 0$-Cymene $(13.21 \%)$, and $\gamma$-Terpinene $(11.76 \%)$ as main compounds. Other compounds with relatively low proportions were also identified: Linalool (4.47\%), Borneol (3.96\%), Z-Caryophyllene- (Z) (2.56\%), Thymol (2.09\%), $\alpha$ terpinene $(2.03 \%)$. The results of the antibacterial tests showed a significant inhibition of bacterial growth. Thymus zygis's essential oil induced inhibition diameters from 14.00 to $45.00 \mathrm{~mm}$. This suggests that the use of Thymus zygis's essential oil could contribute to a better protection of human beings against diseases caused by these bacteria.
\end{abstract}

Key words: biotic components, floristic, El Bhayed, The fauna, environmental degradation.

\section{INTRODUCTION}

The generic name "thyme" includes a set of spontaneous aromatic and medicinal plants that belong to the botanical family named lamiaceae and the genus Thymus. Spread in the Mediterranean area and in Asia as well [1], these species are very resistant to extreme climatic conditions such as cold and aridity [2]. Their importance in traditional and alternative medicine is well known and their essential oils (HE) are endowed with antibacterial [3], antifungal [4] and antioxidant activities [5].

In Morocco, the genus Thymus commonly denominated "zaître" or "Azoukeni" by the local populations is represented by 21 species of which 12 are endemic species [6]. Some of these species have already been deeply scientifically studied while others remain little known. This is particularly the case for Thymus zygis. This species, mainly found in the High Atlas, Middle Atlas, Middle Atlantic regions in Morocco, [7] is generally used against respiratory infections, acute bronchial affections and colds. The use of its essential oil in aromatherapy, pharmaceutics, perfumery, cosmetics and food industry [8] suggests the wide potentiality of its constituents regarding biological activities.

Therefore, with the aim to continue highlighting the potentialities of Thymus zygis, we focused our work on the species from Timahdite. According to our knowledge, for this specific species, only the antibacterial activity against the plant pathogen Erwinia amylora was evaluated by Yakoubi et al. [9].

This work aims to characterize the chemical composition and evaluation of the antibacterial activity of Thymus zygis's essential oil from Timahdite (Moroccan Middle Atlas).

\section{MATERIAL AND METHODS}

Material:

Plant material:

For this work, the leaves of Thymus zygis are required and samples were harvested in May and June 2013 in Timahdite (Moroccan Middle Atlas) at an altitude of 1000 meters. Then, they were shade dried for 15 days. The botanical identification of the species was done at the Scientific Institute of Rabat (Morocco) (Figure1). 

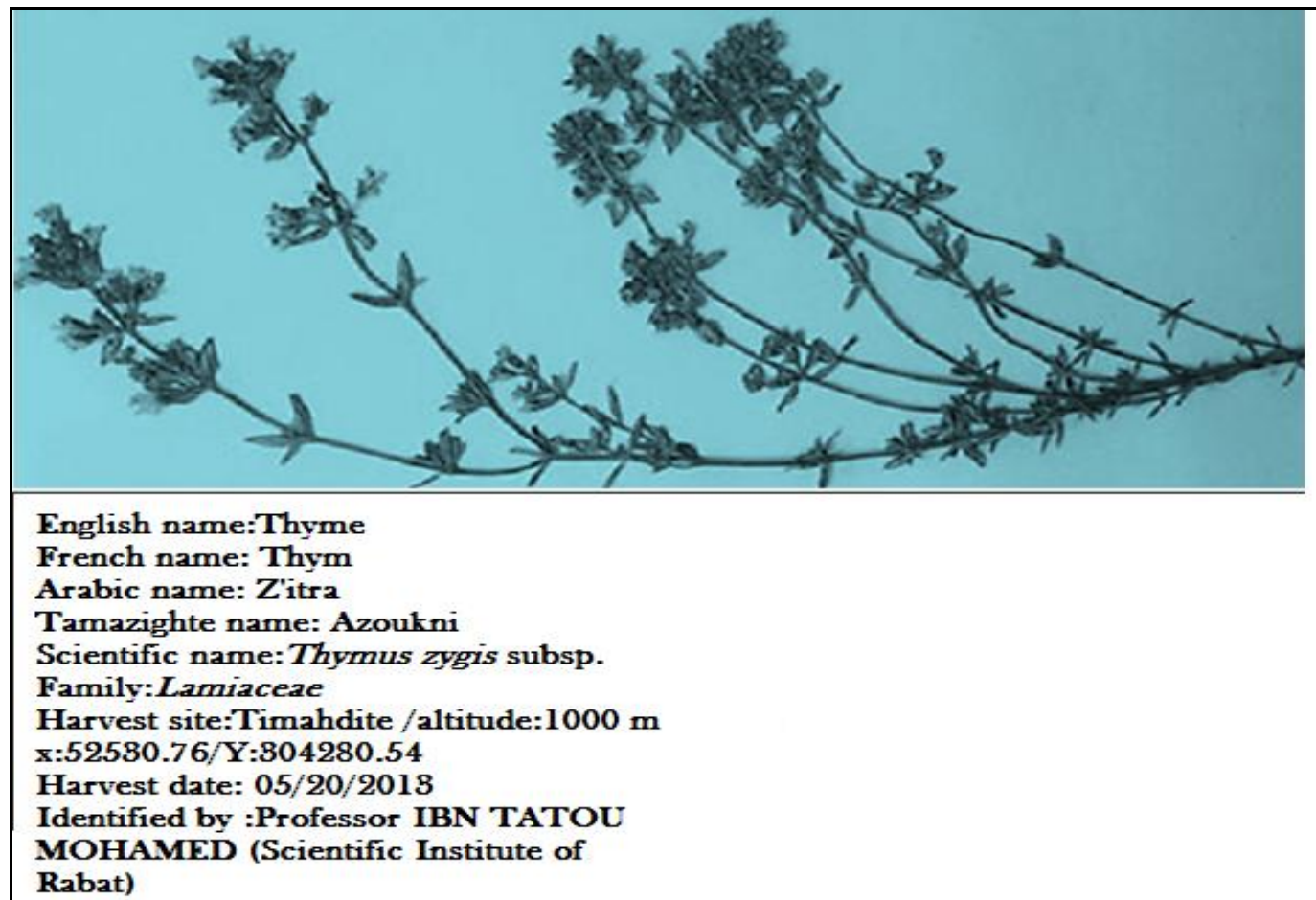

Fig. 1: The herbarium of Thymus zygis subsp. gracilis (Boiss.)

Bacterial species:

To assess the antibacterial activity of Thymus zygis subsp. gracilis (Boiss.)'s essential oil, five pathogenic bacteria were chosen. The set of bacterial strains includes positive and negative-Gram bacteria. They are as follows: Klebsiella pneumonia (Kp) (negative Gram), Staphylococcus aureus (Sa) (positive Gram), Pseudomonas aeruginosa (Pa) (negative Gram), wild-type Escherichia coli (EC1) (negative Gram) and penicillinase-producing Escherichia coli (EC2). The sensitivity of these strains to antibiotics was determined by antibiogram. These bacteria are maintained by subculture on agar nutrient medium. The selected bacterial strains, known for their invasiveness and toxicity towards human beings, have been clinically isolated from the medical laboratory Saïss in Fès city.

Methods:

Extraction of Thymus zygis subsp. gracilis (Boiss.) 's essential oil:

The extraction of Thymus zygis subsp. gracilis (Boiss.)'s essential oil was performed by hydrodistillation. 100 grams of dry plant matter were immersed into one liter of distilled water in a round-bottom. The Clevenger apparatus and Allihn condenser were then joined to this flask and the mixture (plant-water) was finally boiled for three hours. During the process, plant cells burst due to the heat and release the odorous molecules contained therein. These molecules are carried by water steam throughout the Clevenger. Then, the steam is condensed and the essential oil and water are separated depending on their density. At the end of the distillation process, the essential oil is collected, measured in $\mathrm{ml}$ and dried on anhydrous sodium sulphate (Na2SO4). The essential oil is finally introduced into dark glass bottles to be protected from light and tightly sealed. The flasks are kept at $4^{\circ} \mathrm{C}$. In our experiment, the extraction process was repeated three times under the same conditions to determine the average yield of EO expressed in ml per $100 \mathrm{~g}$ of plant matter.

\section{Chromatographic analysis:}

Separation of essential oil's compounds was achieved by gas chromatography $(\mathrm{GC})$ on an apolar column. Right after this separation, the compounds were analyzed by Mass spectrometry (MS). The operating conditions are explained below:

The chromatographic analysis of Thymus zygis's essential oil was carried out on a Thermo electron chromatograph: Trace GC Ultra equipped with a capillary column DB-5 (5\% phenyl-methyl-siloxane) $(30 \mathrm{~m} \times 0.25 \mathrm{~mm}$, film thickness: $0.25 \mu \mathrm{m})$, a flame ionization detector (FID) powered by a mixture of $\mathrm{H}_{2} /$ Air gas. Nitrogen was used as a carrier gas with a $1 \mathrm{ml} / \mathrm{min}$ flow rate. The device is equipped with a split-splitless PVT (Programmed Vaporization Temperature) injector. The selected injection mode is split (leakage ratio: $1 / 50$, flow rate: $66 \mathrm{ml} / \mathrm{min}$ ) and the injected volume is $1 \mu \mathrm{l}$. The experimental temperature rises from 50 to $200{ }^{\circ}$ C with a $4{ }^{\circ} \mathrm{C} / \mathrm{min}$ gradient.

Mass spectrometry was performed with a Thermo electron Trace MS system gas chromatograph (Termoelectron: Trace GC Ultra, Polaris Q MS). Electronic impact fragmentation was applied with $70 \mathrm{eV}$ intensity. A DB-5 MS capillary column was used $(5 \%$ phenyl-methyl-siloxane) $(30 \mathrm{~m} \times 0.25 \mathrm{~mm}$, film thickness: $0.25 \mu \mathrm{m})$. The column temperature rises from 50 to $200{ }^{\circ} \mathrm{C}$ at $4{ }^{\circ} \mathrm{C} /$ min-gradient. Helium is used as a carrier gas with a $1.5 \mathrm{ml} / \mathrm{min}$ flow rate. The split-mode injection was chosen (leakage ratio: $1 / 70, \mathrm{ml} / \mathrm{min}$ flow). The masse range is $30-500 \mathrm{~m} / \mathrm{z}$. The device is connected to a computer system that manages a mass spectra library NIST 98

The compounds of Thymus subsp gracilis's essential oil are identified by comparing the calculated retention indices for each of the eluted compounds with retention indices mentioned in the available databases: Adams 2007 [10] and National Institute of Standards and Technology (NIST) (http://webbook.nist.gov/chemistry/). Retention indices are calculated on the basis of the retention times of a hydrocarbon standard (C7 -C40).The mass spectra of each compound are also compared with those of the databases mentioned above. The retention indices are calculated according to the formula below:

$R I=\left[\frac{T_{x}-T_{n}}{T_{n+1}-T_{n}}+n\right] * 100$

$\mathrm{RI}=$ Retention Index

$\mathrm{T}_{\mathrm{x}}$ : Retention Time of compound $\mathrm{x}$ to be identified.

$\mathrm{T}_{\mathrm{n}}$ : Retention time of the hydrocarbon (with $\mathrm{n}$ number of carbon atoms) eluted before the compound $\mathrm{x}$.

$\mathrm{T}_{\mathrm{n}+1}$ : Retention time of the hydrocarbon (with $\mathrm{n}+1$ number of carbon atoms) eluted after the compound $\mathrm{x}$.

$\mathrm{n}$ : number of carbon atoms of the hydrocarbon eluted before the compound $\mathrm{x}$. 


\section{Antibacterial activity:}

For the evaluation of the antibacterial activity of Thymus zygis subsp. gracilis's essential oil, we chose two complementary in vitro techniques: the disk diffusion method, also known as aromatogram [11,12] and the macrodilution in liquid medium to determine essential oil's Minimal Inhibitory Concentrations (MIC) and Bactericide ones (MBC).

Disk diffusion method (aromatogram)

This method is strongly linked to essential oils' migratory property and their ability to inhibit bacterial growth in a 90 mm-diameter Petri dish that contains agar nutrient medium $[13,14]$. After essential oil's diffusion, an inhibition zone or halo appears. The diameter of this area is an important parameter for the antibacterial activity appraisal.

In practice, the technique consists in using sterile $6 \mathrm{~mm}$ - diameter filter paper disks which we gently deposit onto a culture medium surface (Mueller Hinton) that was previously inoculated with a bacterial inoculum. Then, disks are impregnated with two (2) $\mu l$ of the essential oil to be tested. In the same Petri dishes, we insert positive and negative controls. The negative controls consist of filter paper disks impregnated with two (2) $\mu$ of sterile physiological saline. This control aims to check the bacterial growth in our experimental conditions. The positive controls are the following antibiotics: Imipenem (10 $\mu \mathrm{g} / \mathrm{disk})$ and Amoxicillin ( $25 \mu \mathrm{g} / \mathrm{disk})$ Inhibition diameters are measured in millimetres after a 24 hour- incubation period at $37{ }^{\circ} \mathrm{C}$. During the experiment, each test was repeated thrice in order to minimize the experimental error.

$>$ Macrodilution in liquid medium

The purpose of the macrodilution method is to determine minimum inhibitory concentrations (MICs) and minimum bactericidal concentrations (MBC) of Thymus zygis's essential oil.

First, we prepared the essential oil stock by mixing essential oil with dimethyl sulfoxide (DMSO). The applied ratio was 30/70 (HE / DMSO: v / v). We vortexed enough to obtain a homogeneous stock solution. From this solution, we took very precise volumes to have the following final concentrations: 0.18 ; 0.35 ; $0.70 ; 1.40 ; 2.80 ; 5.60 ; 11.20 ; 22.40$ and $44.80(\mu \mathrm{l} / \mathrm{ml})$. These volumes were aseptically added, into a series of test tubes that contained sterile Mueller Hinton broth. All the tubes containing $3.96 \mathrm{ml}$ of the test solution each (broth medium $+\mathrm{HE}$ ), were inoculated with $40 \mu \mathrm{l}$ of a standardized inocula. The final volume in each tube was $4 \mathrm{ml}$. After a 18-24 hour incubation period at $37^{\circ} \mathrm{C}$, the MIC of Thymus zygis's essential oil corresponds to the lowest concentration for which no visible growth of the germ can be observed in the tube.

Then, to determine the MBC, we inoculated Mueller-Hinton (GMH) plates with $100 \mu$ aliquot withdrawn from tubes that contained essential oil concentrations greater or equal to the MIC. MBC is the smallest concentration that completely inhibits bacterial growth. Moreover, the MBC / MIC ratio was calculated in order to assess essential oil's antibacterial power.

\section{RESULTS AND DISCUSSION}

Essential oil yield of Thymus zygis subsp. gracilis (Boiss.):

The average yield of Thymus zygis's essential oil, expressed in milliliter per $100 \mathrm{~g}$ of dry matter, is $2.37 \pm 0.04 \%$. In comparison to Thymus zygis samples from Timahdite studied by Yakoubi et al., [9], the yield we obtained in our study is relatively low. We precise that Yakoubi et al. have found $4-5.4 \%$ as EO yields for samples collected before, during and after the plant flowering period. Therefore, it appears from the comparison that the yield of essential oil varies significantly despite the fact that we were working on the same species (Thymus zygis) harvested in the same region (Timahdite) and in the same season (May-June). Compared to the yield of the same species harvested in full bloom in the region of Khénifra which value is 1.90\% [15], Thymus zygis from Timahdite seems to be an essential oilrich species (2.37\%). However, this yield (2.37\%) remains generally lower than the yields of the same species from Azrou (3.4-3.6\%) and ElHajeb (1.9-3.9\%) [9].

This yield shows that Thymus zygis from Timahdite is richer than Thymus algeriensis from Wiwan (Khenifra) which provided 1.40\% of essential oil [15]. The yield of Thymus zygis in our study remains higher than that of Thymus satureioides collected in the Moroccan Middle Atlas region (1.1\%) [16] but it is lower than that of Thymus satureioides from the High Atlas which value was $2.74 \mathrm{ml}$ per 100g of dry matter [17].

From the results of the literature and those obtained in this work, it seems that essential oil yields significantly vary. Many authors also mention the influence of several factors such as the harvest period, the harvesting site, the extraction technique and the age of the plant [18].

Chemical composition of Thymus zygis subsp. gracilis (Boiss.)'s essential oil:

Through chromatographic analysis coupled with the mass spectrometry we identified 95 compounds in Thymus zygis's leaves' EO, i.e. $87.53 \%$ of the total EO. The results are gathered in Table 1.

Table 1: Chemical composition of Thymus zygis subsp. gracilis (Boiss.)'s essential oil.

\begin{tabular}{|c|c|c|c|c|}
\hline $\mathrm{N} \circ$ & Compounds & Kováts's Indices & Formulae & Percentages \% \\
\hline 1 & Norbornene-5-methylene-2 & 807 & $\mathrm{C}_{8} \mathrm{H}_{10}$ & $\operatorname{Tr}$ \\
\hline 2 & 3,3,5-trimethyl Cyclohexene, & 831 & $\mathrm{C}_{9} \mathrm{H}_{16}$ & $\operatorname{Tr}$ \\
\hline 3 & Santolina triene & 908 & $\mathrm{C}_{10} \mathrm{H}_{16}$ & 0.01 \\
\hline 4 & Heptanone 3-methyl-4 & 918 & $\mathrm{C}_{8} \mathrm{H}_{16} \mathrm{O}$ & 0.01 \\
\hline 5 & Tricyclene & 926 & $\mathrm{C}_{10} \mathrm{H}_{16}$ & 0.08 \\
\hline 6 & $\alpha$-Thujene & 930 & $\mathrm{C}_{10} \mathrm{H}_{16}$ & 1.45 \\
\hline 7 & $\alpha$-pinene & 939 & $\mathrm{C}_{10} \mathrm{H}_{16}$ & 1.40 \\
\hline 8 & $\beta$-phellandrene & 1029 & $\mathrm{C}_{10} \mathrm{H}_{16}$ & 0.06 \\
\hline 9 & Camphene & 954 & $\mathrm{C}_{10} \mathrm{H}_{16}$ & 1.32 \\
\hline 10 & Thuja-2,4(10)-diene & 960 & $\mathrm{C}_{10} \mathrm{H} 14$ & 0.04 \\
\hline 11 & Sabinene & 975 & $\mathrm{C}_{10} \mathrm{H}_{16}$ & 0.36 \\
\hline 12 & Octen-3-ol -1 & 979 & $\mathrm{C}_{10} \mathrm{H}_{16} \mathrm{O}$ & 0.41 \\
\hline 13 & $\beta$-pinene & 979 & $\mathrm{C}_{10} \mathrm{H}_{16}$ & 1.81 \\
\hline 14 & Octanol-3 & 991 & $\mathrm{C}_{8} \mathrm{H}_{18} \mathrm{O}$ & 0.10 \\
\hline 15 & $\delta$-2-carene & 1002 & $\mathrm{C}_{10} \mathrm{H}_{16}$ & 0.01 \\
\hline 16 & $\alpha$-Phellandrene & 1002 & $\mathrm{C}_{10} \mathrm{H}_{16}$ & 0.38 \\
\hline 17 & $\alpha$-terpinene & 1017 & $\mathrm{C}_{10} \mathrm{H}_{16}$ & 2.03 \\
\hline 18 & P-Cymene & 1024 & $\mathrm{C}_{10} \mathrm{H}_{14}$ & 0.01 \\
\hline 19 & O-Cymene & 1026 & $\mathrm{C}_{10} \mathrm{H}_{14}$ & 13.21 \\
\hline 20 & $\beta$-phellandrene & 1029 & $\mathrm{C}_{10} \mathrm{H}_{16}$ & 0.23 \\
\hline 21 & $\gamma$-Terpinene & 1059 & $\mathrm{C}_{10} \mathrm{H}_{16}$ & 11.76 \\
\hline 22 & cis-Sabinene hydrate & 1070 & $\mathrm{C}_{10} \mathrm{H}_{18} \mathrm{O}$ & 1.36 \\
\hline 23 & Mentha-3,8-diene & 1072 & $\mathrm{C}_{10} \mathrm{H}_{16}$ & 0.26 \\
\hline 24 & Linalool & 1086 & $\mathrm{C}_{10} \mathrm{H}_{18} \mathrm{O}$ & 4.47 \\
\hline 25 & P-Cymene & 1091 & $\mathrm{C}_{10} \mathrm{H}_{14}$ & 0.13 \\
\hline 26 & Terpinolene & 1088 & $\mathrm{C}_{10} \mathrm{H}_{16}$ & 0.18 \\
\hline 27 & Trans -Sabinene hydrate & 1098 & $\mathrm{C}_{10} \mathrm{H}_{18} \mathrm{O}$ & 0.23 \\
\hline 28 & $\mathrm{p}$-Mentha trien $-1,3,8$ & 1110 & $\mathrm{C}_{10} \mathrm{H}_{14}$ & 0.01 \\
\hline 29 & Mentha-trien & 1110 & $\mathrm{C}_{10} \mathrm{H}_{14} \mathrm{O}$ & 0.01 \\
\hline
\end{tabular}


Citation: Kamal Fadili, et al., 2018. Effect of Thymus zygis subsp. gracilis (Boiss.)'s Essential Oil Composition on Human-Pathogenic Bacteria. Advances in Environmental Biology., 12(7): 6-12.

\begin{tabular}{|c|c|c|c|c|}
\hline 30 & 6-Camphenol & 1113 & $\mathrm{C}_{10} \mathrm{H}_{16} \mathrm{O}$ & 0.01 \\
\hline 31 & Fenchol- endo & 1121 & $\mathrm{C}_{10} \mathrm{H}_{18} \mathrm{O}$ & 0.11 \\
\hline 32 & $\alpha$-Camphenol & 1126 & $\mathrm{C}_{10} \mathrm{H}_{16} \mathrm{O}$ & 0.02 \\
\hline 33 & Mentha-2,8-dien-1-ol, cis- $\mathrm{p}$ & 1137 & $\mathrm{C}_{10} \mathrm{H}_{16} \mathrm{O}$ & 0.01 \\
\hline 34 & Trans -Pinocarveol & 1139 & $\mathrm{C}_{10} \mathrm{H}_{16} \mathrm{O}$ & 0.02 \\
\hline 35 & Trans -Sabinol & 1142 & $\mathrm{C}_{10} \mathrm{H}_{16} \mathrm{O}$ & 0.12 \\
\hline 36 & Trans -Verbinol & 1144 & $\mathrm{C}_{10} \mathrm{H}_{16} \mathrm{O}$ & 0.12 \\
\hline 37 & 3,4-octadienal -2,2-Dimethyl & 1103 & $\mathrm{C}_{10} \mathrm{H}_{16} \mathrm{O}$ & 0.04 \\
\hline 38 & Pinene oxide- $\beta$ & 1159 & $\mathrm{C}_{10} \mathrm{H}_{16} \mathrm{O}$ & 0.12 \\
\hline 39 & Isocitral (Z) & 1164 & $\mathrm{C}_{10} \mathrm{H}_{16} \mathrm{O}$ & 0.06 \\
\hline 40 & Borneol & 1169 & $\mathrm{C}_{10} \mathrm{H}_{18} \mathrm{O}$ & 3.96 \\
\hline 41 & Terpinen-4-ol & 1177 & $\mathrm{C}_{10} \mathrm{H}_{18} \mathrm{O}$ & 1.02 \\
\hline 42 & Cymen-8-ol- $\mathrm{m}$ & 1179 & $\mathrm{C}_{10} \mathrm{H}_{14} \mathrm{O}$ & 0.14 \\
\hline 43 & Terpineol- $\alpha$ & 1188 & $\mathrm{C}_{10} \mathrm{H}_{18} \mathrm{O}$ & 0.12 \\
\hline 44 & Cymen-8-ol- $\mathrm{P}$ & 1182 & $\mathrm{C}_{10} \mathrm{H}_{14} \mathrm{O}$ & 0.16 \\
\hline 45 & Dihydrocarveol -neo & 1193 & $\mathrm{C}_{10} \mathrm{H}_{18} \mathrm{O}$ & 0.06 \\
\hline 46 & Terpineol- $\gamma$ & 1199 & $\mathrm{C}_{10} \mathrm{H}_{18} \mathrm{O}$ & 0.14 \\
\hline 47 & Trans -Carveol & 1216 & $\mathrm{C}_{10} \mathrm{H}_{16} \mathrm{O}$ & 0.06 \\
\hline 48 & cis-Carveol & 1129 & $\mathrm{C}_{10} \mathrm{H}_{16} \mathrm{O}$ & 0.06 \\
\hline 49 & Thymol methyl ether & 1235 & $\mathrm{C}_{11} \mathrm{H}_{16} \mathrm{O}$ & 0.10 \\
\hline 50 & Carvacrol methyl ether & 1244 & $\mathrm{C}_{11} \mathrm{H}_{16} \mathrm{O}$ & 0.17 \\
\hline 51 & Trans -Chrysanthenyl acetate & 1238 & $\mathrm{C}_{12} \mathrm{H}_{18} \mathrm{O}_{2}$ & 0.02 \\
\hline 52 & Cuminaldehyde & 1238 & $\mathrm{C}_{10} \mathrm{H}_{12} \mathrm{O}$ & 0.03 \\
\hline 53 & (Z)-Anethole & 1252 & $\mathrm{C}_{10} \mathrm{H}_{12} \mathrm{O}$ & 0.05 \\
\hline 54 & Perillaldehyde & 1271 & $\mathrm{C}_{10} \mathrm{H}_{14} \mathrm{O}$ & 0.02 \\
\hline 55 & 6Verbenyl acetate & 1282 & $\mathrm{C}_{12} \mathrm{H}_{18} \mathrm{O}_{2}$ & 0.01 \\
\hline 56 & $\alpha$-Terpinen-7-al & 1285 & $\mathrm{C}_{10} \mathrm{H}_{14} \mathrm{O}$ & 0.14 \\
\hline 57 & Isobornyl acetate & 1285 & $\mathrm{C}_{12} \mathrm{H}_{20} \mathrm{O}_{2}$ & 0.01 \\
\hline 58 & Thymol & 1289 & $\mathrm{C}_{10} \mathrm{H}_{14} \mathrm{O}$ & 2.09 \\
\hline 59 & Carvacrol & 1299 & $\mathrm{C}_{10} \mathrm{H}_{14} \mathrm{O}$ & 30.54 \\
\hline 60 & 2-Ethyl 5-n-propyl phenyl & 1335 & $\mathrm{C}_{11} \mathrm{H}_{16} \mathrm{O}$ & 0.09 \\
\hline 61 & Thymol, acetate & 1352 & $\mathrm{C}_{12} \mathrm{H}_{16} \mathrm{O}_{2}$ & 0.01 \\
\hline 62 & Carvacrol acetate & 1372 & $\mathrm{C}_{12} \mathrm{H}_{16} \mathrm{O}_{2}$ & 0.48 \\
\hline 63 & $\beta(\mathbf{Z})$-Caryophyllene & 1408 & $\mathrm{C}_{15} \mathrm{H}_{24}$ & 2.56 \\
\hline 64 & Ylangene & 1420 & $\mathrm{C}_{15} \mathrm{H}_{24}$ & 0.03 \\
\hline 65 & Gurjunene & 1433 & $\mathrm{C}_{15} \mathrm{H}_{24}$ & 0.01 \\
\hline 66 & $\alpha$-Guaienene & 1439 & $\mathrm{C}_{15} \mathrm{H}_{24}$ & 0.15 \\
\hline 67 & Aromadendrene & 1441 & $\mathrm{C}_{15} \mathrm{H}_{24}$ & 0.01 \\
\hline 68 & Khusimene & 1455 & $\mathrm{C}_{15} \mathrm{H}_{24}$ & 0.07 \\
\hline 69 & D Germacrene & 1481 & $\mathrm{C}_{15} \mathrm{H}_{24}$ & 0.10 \\
\hline 70 & Epi- Cubenol & 1493 & $\mathrm{C}_{15} \mathrm{H}_{26} \mathrm{O}$ & 0.15 \\
\hline 71 & Cubebol & 1515 & $\mathrm{C}_{15} \mathrm{H}_{26} \mathrm{O}$ & 0.11 \\
\hline 72 & $\alpha$-Selinene-7-epi & 1522 & $\mathrm{C}_{15} \mathrm{H}_{24}$ & 0.13 \\
\hline 73 & $\gamma$-Cadinene & 1523 & $\mathrm{C}_{15} \mathrm{H}_{24}$ & 0.30 \\
\hline 74 & Cis-Calamenene & 1529 & $\mathrm{C}_{15} \mathrm{H}_{22}$ & 0.09 \\
\hline 75 & 10-epi Cubenol & 1535 & $\mathrm{C}_{15} \mathrm{H}_{26} \mathrm{O}$ & 0.02 \\
\hline 76 & Hedycaryol & 1548 & $\mathrm{C}_{15} \mathrm{H}_{26} \mathrm{O}$ & 0.02 \\
\hline 77 & $\beta$-Calacorene- & 1565 & $\mathrm{C}_{15} \mathrm{H}_{20}$ & 0.02 \\
\hline 78 & $\alpha$-Cedrene epoxide & 1575 & $\mathrm{C}_{15} \mathrm{H}_{24} \mathrm{O}$ & 0.03 \\
\hline 79 & Germacrene D-4 ol & 1575 & $\mathrm{C}_{15} \mathrm{H}_{26} \mathrm{O}$ & 0.01 \\
\hline 80 & Ledene oxide & 1630 & $\mathrm{C}_{15} \mathrm{H}_{24} \mathrm{O}$ & 0.03 \\
\hline 81 & Spathulenol & 1578 & $\mathrm{C}_{15} \mathrm{H}_{24} \mathrm{O}$ & 0.60 \\
\hline 82 & Thujopsene-2- $\alpha-\mathrm{ol}$ & 1587 & $\mathrm{C}_{15} \mathrm{H}_{26} \mathrm{O}$ & 0.66 \\
\hline 83 & Epi-Cedrol & 1619 & $\mathrm{C}_{15} \mathrm{H}_{26} \mathrm{O}$ & 0.01 \\
\hline 84 & Ledol & 1602 & $\mathrm{C}_{15} \mathrm{H}_{26} \mathrm{O}$ & 0.03 \\
\hline 85 & Cubenol & 1646 & $\mathrm{C}_{15} \mathrm{H}_{26} \mathrm{O}$ & 0.17 \\
\hline 86 & Agarospirol & 1648 & $\mathrm{C}_{15} \mathrm{H}_{26} \mathrm{O}$ & 0.02 \\
\hline 87 & Torreyol & 1646 & $\mathrm{C}_{15} \mathrm{H}_{26} \mathrm{O}$ & 0.02 \\
\hline 88 & cis-Guaren-3,9-dies-11-ol & 1649 & $\mathrm{C}_{15} \mathrm{H}_{24} \mathrm{O}$ & 0.07 \\
\hline 89 & Cedr-8(15)-en-10-ol & 1652 & $\mathrm{C}_{15} \mathrm{H}_{24} \mathrm{O}$ & 0.06 \\
\hline 90 & Valerianol & 1658 & $\mathrm{C}_{15} \mathrm{H}_{26} \mathrm{O}$ & 0.14 \\
\hline 91 & Eudesmol-7-epi- $\alpha$ & 1662 & $\mathrm{C}_{15} \mathrm{H}_{26} \mathrm{O}$ & 0.16 \\
\hline 92 & Guaia-3,10(14)-dien-11-ol & 1677 & $\mathrm{C}_{15} \mathrm{H}_{24} \mathrm{O}$ & 0.01 \\
\hline 93 & Occidentalol acetate & 1682 & $\mathrm{C}_{17} \mathrm{H}_{26} \mathrm{O}_{2}$ & 0.16 \\
\hline 94 & Eudesm-7(11)-en-4-ol. & 1700 & $\mathrm{C}_{15} \mathrm{H}_{26} \mathrm{O}$ & 0.11 \\
\hline 95 & Acoradrenol- $\beta-$ & 1763 & $\mathrm{C}_{15} \mathrm{H}_{24} \mathrm{O}$ & 0.03 \\
\hline \multicolumn{4}{|c|}{ Total \% } & 87.53 \\
\hline
\end{tabular}

This EO mainly consists of carvacrol (30.54\%), O-cymene (13.21\%) and $\gamma$-terpinene (11.76\%). Other compounds with relatively low proportions like linalool (4.47\%), borneol (3.96\%), Z-caryophyllene- (Z) (2.56\%), thymol (2.09\%), $\alpha$-terpinene (2.03\%) were also identified. Monoterpene hydrocarbons and oxygenated monoterpernes constitute the predominant terpene subclasses in this essential oil with $34.48 \%$ and $46.95 \%$ respectively while sesquiterpene hydrocarbons and oxygenated sesquiterpenes represent only $3.47 \%$ and $2.62 \%$ of the composition (Table 2 ).

Research on Thymus zygis from three regions of Moroccan Middle Atlas (El Hajeb, Azrou and Timahdite) showed that the three samples of this species are mainly composed of carvacrol (16.07 to $74.33 \%$ ), thymol (1.47 to $32.46 \%)$, p-cymene (6.97 to $40.26 \%)$ and $\gamma$-terpinene (2.68 to $22 \%)$ [9]. In these samples, the compounds are similar to ours with slight variation regarding proportions. 
Citation: Kamal Fadili, et al., 2018. Effect of Thymus zygis subsp. gracilis (Boiss.)'s Essential Oil Composition on Human-Pathogenic Bacteria. Advances in Environmental Biology., 12(7): 6-12.

Table 2: Terpene subclasses and their proportions in Thymus zygis subsp. gracilis (Boiss.)'s essential oil.

\begin{tabular}{|l|ll|ll|}
\hline \multirow{2}{*}{ Terpene subclasses } & {$[2]$ Thymus zygis 's leaves' essential oil } & \\
\cline { 2 - 5 } & {$[3]$} & Number of identified compounds & {$[4]$} & $\%$ \\
\hline$[5]$ Monoterpene hydrocarbons & {$[6]$} & 19 & {$[7]$} & 34.48 \\
\hline$[8]$ oxygenated monoterpenes & {$[9] \quad 40$} & {$[10]$} & 46.95 \\
\hline$[11]$ Sesquiterpene hydrocarbons & {$[12] 11$} & {$[13]$} & 3.47 \\
\hline$[14]$ oxygenated sesquiterpenes & {$[15] 22$} & {$[16] 2.62$} \\
\hline$[17]$ other & {$[18] 3$} & {$[19]$} & 0.01 \\
\hline$[20]$ Total $\%$ & {$[21]$ 95 } & {$[22] 87.53$} \\
\hline
\end{tabular}

In the region of Ozoud-Azilal (High Atlas of Morocco), Thymus zygis's EO is dominated by thymol (34.07\%) instead of carvacrol (thymol isomer) and borneol is found in this oil with a significant proportion $(25.28 \%)$ [19].

In their study on samples of Thymus zygis from the region of Khenifra, Belmalha et al[14]., have highlighted a composition similar to the previously mentioned samples with thymol as main compound. The essential oil composition is as follows: thymol (38.04\%); p-cymene (18.94\%); $\gamma$-terpinene (12.5\%), carvacrol (11.6\%) and borneol (6.63\%).

For T. zygis from the Taza region, the chemical composition is marked by the presence of thymol (37.5\%), $\gamma$-terpinene (29.7\%) and p-cymene (12.1\%) as compounds majority [20].

Moldão-Martins et al [21] revealed that in the north of Portugal, thymol (23.8\%) is the main compound and the essential oil also contains geraniol (18.2\%), pcymene $(13.6 \%)$ and acetate geranyl $(16.3 \%)$. However, Machado et al. [22] published different results from their work on samples from Portugal. According to these researchers, the oil is dominated by p-cymene (36.6\%), $\gamma$-Terpinene (21\%) and thymol (15\%).

In Spain, several samples of Thymus zygis studied by Richard et al. [23] provided thymol and carvacrol-rich EOs. They are dominated by thymol (1.1 to $30.7 \%)$ or carvacrol (6.5 to $42.9 \%)$ and other constituents such as p-cymene (23.3 to $28.5 \%)$, caryophyllene oxide (1.5 to $9.8 \%$ ), linalool (1.5 to $4 \%$ ) and thymol methyl ether (0 to $4.5 \%)$.

Thymus zygis'EO from the region of Paca in France is characterized by the thymol chemotype (84.9\%), other components like p-cymene (9.7\%), $\gamma$-terpinene $(2.3 \%)$ and linalool $(1.4 \%)$ are also present [24].

From these studies, we note that in Europe, Thymus zygis is most often characterized by high proportions of thymol and its chemical composition is quite similar to the Moroccan's.

Regarding the systematically close species: T. munbyanus and T. algeriensis from the region of Khenifra, Belmalha et al.[15], found similar composition for the EOs of these three species T. zygis; T. munbyanus and T. algeriensis. EO compositions were as follows: for T. zygis, thymol (38.04\%); p-cymene (18.94\%); $\gamma$ terpinene (12.5\%), carvacrol (11.6\%) and borneol (6.63\%), for T. munbyanus: Thymol (24.02\%); p-cymene (18.95\%); $\gamma$-terpinene (23.35\%); carvacrol (10.84\%) and borneol (7.53\%). The compounds of T. algeriensis are: thymol (37.07\%); p-cymene (17.3\%); $\gamma$-terpinene (16.3\%); borneol (8.43\%) and carvacrol (0.09\%).

It may be concluded that thymol and / or carvacrol are the major compounds in most thyme essential oils. Nevertheless, non-cyclic terpenes may also be identified as major constituents [25].

Antibacterial activity:

$>$ Disk diffusion method:

In order to contribute to Thymus zygis's essential oil's valorization, we have performed antibacterial tests against bacterial strains responsible for human infections.

Table 3 and figure 2 point out the results of the susceptibility test of Thymus zygis's essential oil.

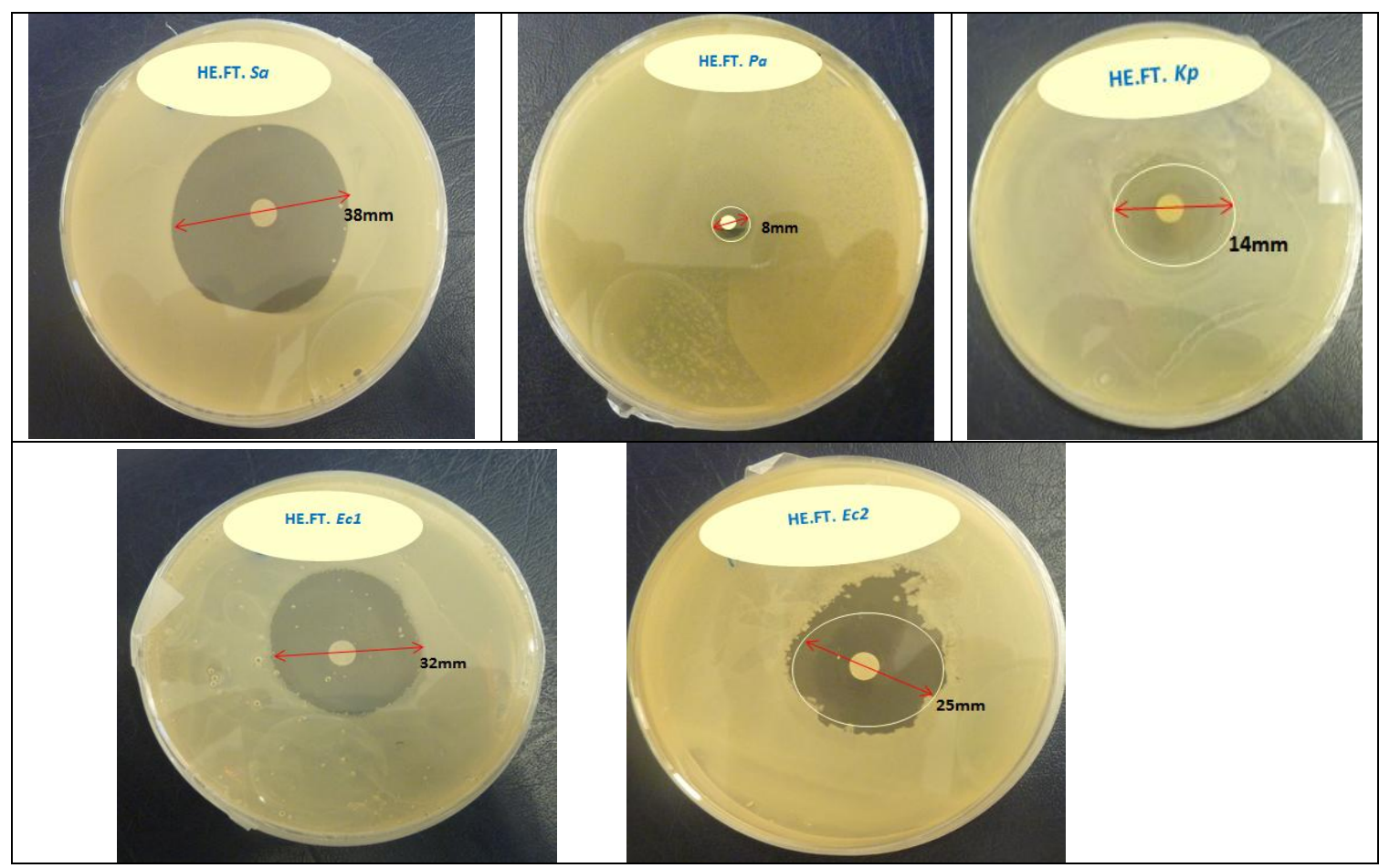

Fig. 2: Diameters of inhibition zones exerted by Thymus zygis's essential oil towards S. aureus, P. aeruginosa, E. coli1, E. coli2 and K. pneumoniae

Results in Table 3 show that Thymus zygis's EO exhibits a weak antibacterial effect on P. aeruginosa. This results is marked by a small diameter (8mm) of the inhibition zone. This corresponds to the weakest antibacterial activity. Despite this small diameter of inhibition, this result is still important since $P$. aeruginosa is among those bacteria that have developed multi resistance to antibacterial agents. Regarding the other bacteria, they showed a variable sensitivity. The essential oil is very active against $S$. aureus. Its action towards this strain has led to the largest inhibition diameter $(38 \mathrm{~mm})$. For E. coli, Thymus zygis's EO exhibited a significan antibacterial activity with a $32 \mathrm{~mm}$-inhibition diameter for E.coli 1 and $25 \mathrm{~mm}$ for $E$. coli2. These are the most significant results after $S$. aureus 's. It is important to 
Citation: Kamal Fadili, et al., 2018. Effect of Thymus zygis subsp. gracilis (Boiss.)'s Essential Oil Composition on Human-Pathogenic Bacteria. Advances in Environmental Biology., 12(7): 6-12.

note that these strains E. coli 2 and E. coli 1 are respectively resistant and intermediate to amoxicillin. It should also be noted that Thymus zygis's EO showed moderate antibacterial activity against $K$. pneumoniae with a 14 mm-inhibition diameter.

Table 3: Diameters of inhibition zones due to Thymus zygis's essential oil towards S. aureus, P. aeruginosa, E. coli and K. Pneumonia.

\begin{tabular}{|c|c|c|c|c|}
\hline \multirow{2}{*}{ Bacterial strains } & \multicolumn{4}{|c|}{ Diameters* of inhibition zones in $\mathrm{mm}$} \\
\hline & T.Zygis's essential oil & Imipenem $10 \mu \mathrm{g}$ & 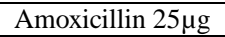 & Negative control \\
\hline S. aureus & 38.00 & $61.00 \pm 1.00$ & $19.50 \pm 0,50$ & 06.00 \\
\hline P. aeruginosa & 08.00 & $25.00 \pm 0.00$ & $06.00 \pm 0.00$ & 06.00 \\
\hline E. coli $_{1}$ & 32.50 & $34.00 \pm 0.7$ & $20.00 \pm 0.5$ & 06.00 \\
\hline penicillinase-producing $E$. coli $_{2}$ & 25.00 & $26.00 \pm 00$ & $06.0 \pm 0.0$ & 06.00 \\
\hline K. pneumoniae & 14.00 & $28.00 \pm 1.00$ & $06.00 \pm 0.00$ & 06.00 \\
\hline
\end{tabular}

Thus, on the basis of our results, it could be said that Thymus zygis's essential oil exerts its antibacterial activity regardless of the Gram status and antibiogram profile. Nevertheless, antimicrobial activity against $P$. aeruginosa remains very weak.

Our results are similar to those of Rota et al. [3], who found that $T$. Zygis's essential oils showed excellent antibacterial activity with Staphylococcus aureus's sensitivity greater than Escherichia coli's. Conversely, Kaloustian et al. [23], found that Escherichia coli strain is more sensitive than Staphylococcus aureus to thymol-rich and carvacrol-rich thyme essential oils. Yakoubi et al. in 2014[15] found that carvacrol and thymol-rich Thymus Zygis's essential oils from Azrou, El Hajeb and Timahdite showed excellent antibacterial activity against Erwinia amylovora a plant pathogen with diameters above $50 \mathrm{~mm}$. Indeed, several authors have shown that phenolic-derivative-rich essential oils have a strong antimicrobial activity (e.g. carvacrol and thymol-rich essential oils). Dorman and Deans [26], who worked on 25 bacteria genus, have shown that thymol is the compound with the broadest antibacterial spectrum. Lambert et al. [27] added by explaining that thymol binds to membrane proteins and increases the permeability of the bacterial cell membrane. The same mechanism could apply for carvacrol given the common characteristics of these two compounds.

\section{$>\quad$ Macrodilution in liquid medium:}

Determination of minimum inhibitory (MIC) and bactericidal (MBC) concentrations of Thymus zygis's essential oil is summarized by Table 4. The MBC / MIC ratio helps appraise the bacteriostatic or bactericidal activity of an essential oil: when this ratio is below 4 , the essential oil is considered bactericidal and the essential oil is bacteriostatic for a ratio above 4 [28]

Table 4: Minimum inhibitory concentrations (MIC) and Minimum bactericidal concentrations (MBC) concentrations of Thymus zygis's leaves' essential oil (in $\mu \mathrm{l} / \mathrm{ml})$.

\begin{tabular}{|c|c|c|c|c|}
\hline Bacterial strains & $\operatorname{MIC}(\mu \mathrm{l} / \mathrm{ml})$ & $\operatorname{MBC}(\mu \mathrm{l} / \mathrm{ml})$ & $\frac{\mathrm{MBC}}{\mathrm{MIC}}$ & Effect \\
\hline S. aureus & 2.4 & 3.6 & 1.5 & Bactericidal effect \\
\hline P. aeruginosa & 4.8 & 12 & 2.5 & Bactericidal effect \\
\hline E. coli $_{1}$ & 1.2 & 1.8 & 1.5 & Bactericidal effect \\
\hline E. coli $_{2}$ & 4.8 & 12 & 2.5 & Bactericidal effect \\
\hline K. pneumoniae & 0.6 & 0.96 & 1.6 & Bactericidal effect \\
\hline
\end{tabular}

MBC

All $\overline{\text { MIC }}$ ratios are below 4 meaning that Thymus zygis's essential oil exerts a bactericidal effect towards these pathogenic strains. The value of $\overline{\text { MIC }}$ ratio is 2.5 for $P$. Aeruginosa, and it equals 2.5 and 1.6 respectively for E. coli $i_{2}$ and $K$. pneumonia. The same value of the ratio (1.5) is obtained for E. coli $I_{1}$ and $S$. aureus (table 4). The bactericidal effect of this essential oil on the pathogenic strains could be attributed to the high proportion of carvacrol [29]. However, it should be taken into account that other compounds like linalool or thymol despite their low proportions could contribute to the observed antibacterial activity.

Other researchers like Yakoubi et al. [15], have noticed similar results when they found that carvacrol, thymol and p-cymene-rich essential oils of Thymus zygis from Moroccan Middle Atlas exhibit a bactericidal effect against Erwinia amilovora which is responsible for the fire blight.

In addition, Fadili et al. [17] have revealed a significant antibacterial activity of another thyme species Thymus satureioides which essential oil was mainly composed of carvacrol. In that experiment, the MICs against Staphylococcus aureus and Klebsiella pneumoniae were $2.72 \mathrm{mg} / \mathrm{ml}$ and $0.68 \mathrm{mg} / \mathrm{ml} \mathrm{respectively}$. Towards Pseudomonas aeruginosa the MIC was $2.72 \mathrm{mg} / \mathrm{ml}$ while it reached $5.44 \mathrm{mg} / \mathrm{ml}$ against a wild strain of Eschirichia coli and $21.73 \mathrm{mg} / \mathrm{ml}$ against penicillinase-producing Escherichia coli.

Besides, El Bouzidi Laila et al [30] have found that Thymus maroccanus's essential oil is very active against the same bacterial species. MICs values were as follows: Staphylococcus aureus $0.3 \mathrm{mg} / \mathrm{ml}$; Klebsiella pneumoniae: $0.58 \mathrm{mg} / \mathrm{ml}$; Escherichia coli: $0.58 \mathrm{mg} / \mathrm{ml}$ and Pseudomonas aeruginosa $>18.6 \mathrm{mg} / \mathrm{ml}$. The main compounds were again carvacrol and thymol.

All these studies strengthen the hypothesis claiming that the antibacterial activity of $T$. Zygis's essential oil from Timahdite could be carvacrol's effect.

Conclusion:

T. zygis from Timahdite produced a high-yield essential oil (2.37\%). The chromatographic and spectral analyses used in this study enabled to identify $87.53 \%$ of the essential oil's constituents. The main ones are : Carvacrol (30.54\%), O-Cymene (13.21\%)and $\gamma$-Terpinene (11.76\%). Other compounds such as linalol, borneol, Z-caryophyllene-(Z), thymol and $\alpha$-terpinene were also identified but with low proportions. Thanks to its phenolic and terpene alcohol-rich essential oil, $T$. zygis showed a significant activity against four microorganisms at low concentrations. These encouraging results on sensitive and antibiotic-resistant bacteria need further studies to consider their applications in herbal medicine and /or as food preservatives.

\section{REFERENCES}

[1] Maksimovic, Z., D. Stojanovic, I. Sostaric, Z. Dajic and M. Ristic, 2008. Composition and radical-scavenging activity of Thymus glabrescens. Willd. (Lamiaceae) essential oil. J Sci. Food Agr., 88: 2036-2041.

[2] Morales, R., 2002.The history, botany and taxonomy of the genus Thymus. In: Thyme: the genus Thymus (eds. Stahl-Biskup E \&Sáez F), pp. 1-43. Taylor \& Francis, London.

[3] Rota, M.C., A. Herrera, R.M. Martinez, J.A. Sotomayor and M.J. Jordan, 2008. Antimicrobial activity and chemical composition of thymus vulgaris, thymus zygis and thymus hyemalis essential oils Food control, 19: 681-687.

[4] Goncalves, M.J., M.T. Cruz, C. Cavaleiro, M.C. Lopes and L. Salgueiro, 2010. Chemical, antifungal and cytotoxic evaluation of the essential oil of thymus Zygis subsp. Sylvestris.

[5] Bouhdid, S., M. Idaomar and A. Zihi, 2006. Thymus essential oils:chemical composition and in vitro antioxidant and antibacterial activities. Congrès international de biochimie, 9-12 Mai 2006,Agadir, Maroc.

[6] Benabid, A., 2000. Flore et écosystème du Maroc. Evaluation et préservation de la biodiversité Paris: Edition Ibis Press, 159-161. 
[7] Fennane, M., M. Ibn Tattou, A. Ouyahya and J. El Oulaidi, 2007. Flore pratique du Maroc. vol. 2 Trav. Inst. Sci. Sér. Bot., Rabat.38:1-636. Industrialcrops and products, 32: 70-75.

[8] Cabo, J., J. Jimenez, A. Revert and L. Bravo, 1981. Effects of ecological factors (altitude) on the content and composition of essential oils from the sample of Thymus zygis L collected in different areas. Ars Pharm., 22: 187-94.

[9] Yakoubi, S., A. Cherrat, M. Diouri, F.E.L. Hilali and T. Zair, 2014. Chemical composition and antibacterial activity of Thymus zygis subsp. gracilis (Boiss.) R. Morales essential oils from Morocc.Mediterranean Journal of Chemistry, 3(1): 746-758.

[10] Adams, R.P., 2007. Identification of Essential Oil Components by Gas Chromatography/Mass Spectrometry. 4th edition Allured Publishing Corporation.

[11] Sacchetti, G., S. Maietti, M. Muzzoli, M. Scaglianti, S. Mansredini, M. Radice and R. Irimi, 2005. Comparative evaluation of 11 essentials oils of different origin as functional antioxydants, antiradicals and antimicrobial in food. Food Chemistry, 91: 621-632.

[12] Celiktas, O.Y., E.E. Bedir, F. Vardar Sukan, T. Ozek and K.H.C. Baser, 2007. Antimicrobial activities of methanol extracts and essential oils of Rosmarinusofficinalis, depending on location and seasonal variations. Food Chem., 100: 553-559.

[13] Vinod, K.G., R. Amit, K.N. Vikas and M. Kalishankar, 2010. Antimicrobial activity of Spondiaspinnata resin.Journal of Medicinal Plants Research, 4(16): $1656-1661$.

[14] Billerbeck, V., 2007. Huiles essentielles et bactéries résistantes aux antibiotiques. Phytothérapie, 5: 249-253.

[15] Belmalha, S., M. ELidrissi, A. Amechrouk and G. Echch, 2014. Caractérisation chimique de certainesespèces de thymMarocainduMoyen Atlas (région de Khenifra); ScienceLib: 2014, Volume 6, ${ }^{\circ} 140906$.

[16] El Ouali Lalami, A., F. EL-akhal, W. Ouedrhiri, F. Ouazzani Chahdi, R. Guemmouh and H. Greche, 2013. Composition chimique et activité antibactérienne des huiles essentielles de deux plantes aromatiques du centre nord marocain: Thymus vulagris et Thymus satureioïdis. Les technologies de laboratoire, Volume 8, N³1.

[17] Fadili, K., C. Sekkate, F. Alistiqsa, Z. Haloui, S. Chakir and T. Zair, 2017. Ethnobotanical study of medicinal plants from Er-Rich region (Moroccan High Atlas). Advances in Environmental Biology, 11(6): 27-40.

[18] Aberchane, M., M. Fechtal, A. Chaouch and T. Bouayoune, 2001. Influence de la duréeet de la technique d'extractionsur le rendement et la qualité des huilesessentielles du cèdre de l'Atlas (Cedrusatlanticamanetti). Annales de la rechercheforestière au Maroc ISSN 0483-8009 CODEN AFRMA., 34: 110118.

[19] Jaafari, A., H. Ait Mouse, E. Rakib, L. Ait M’barek, M. Tilaou, C. Benbakhta, A. Boulli, A. Abbad and A. Zyad, 2007. Chemical composition and antitumor activity of different wildvarieties of Moroccan thyme. Braz. J. Pharmacogn, 17(4): 477-491.

[20] Zayyad, L., A. Farah and J. Bahhou, 2014. Analyse chimique et activité antibactérienne des huiles essentielles des trois espèces de Thymus : Thymus zygis, T. algeriensis et T. bleicherianus. Bulletin de la Société Royale des Sciences de Liège, 83: 118-132.

[21] Moldão-Martins, M., M.G. Bernardo-Gil, M.L. Beirão da Costa and M. Rouzet, 1999. Seasonal variation in yield and composition of Thymus zygis L. subsp. sylvestris essential oil Flavour and fragrance journal, 14(3): 177-182.

[22] Machado, M., C.M. Sousa, L. Salgueiro and C. Cavaleiro. 2010. Effects of essential oils on the growth of Giardia lamblia trophozoites. Natural Product, 5(1): 137-141.

[23] Richard, H., B. Benjilali, N. Banquour and O. Baritaux, 1985. Etude de diverses huiles essentielles de thym du Maroc Lebensm-wiss.u-Technol., 18: 105110.

[24] Kaloustian, J., J. Chevalier and C. Mikail, 2008. Étude de six huiles essentielles: composition chimique et activité antibactérienne. Phytothérapie, 6(3): 1604.

[25] Bellakhdar, J., 1997. La Pharmacopée marocaine traditionnelle: Médecine arabe ancienne et saviors populaires, Paris, Ibis Press, 764.

[26] Dorman, H.J.D. and S. Deans, 2000. Antimicrobial agents from plants: antimicrobial activity of plant volatile oils. J. Appl. Microbiol., 88: 308-16.

[27] Lambert, R., P.N. Skandamis, P. Coote and G. Nychas, 2001. A study of the minimum inhibitory concentration and mode of action of oregano essential oil, thymol and carvacrol. J. Appl. Microbiol.

[28] Mourey, A. and N. Canillac, 2002. Anti-Listeria monocytogenes activity of essential oils components of conifers.Food Control, 13: $289-292$.

[29] Kalemba, D. and A. Kunicka, 2003. Antibacterial and antifungal properties of essential oils. Current Med. Chem., 10(10): 813-29.

[30] El Bouzidi, L., C. Alaoui Jamali, K. Bekkouche, L. Hassani, H. Wohlmuth, D. Leach and A. Abbad, 2013. Chemical composition, antioxidant and antimicrobial activities of essential oils obtained from wild and cultivated Moroccan Thymus species. Ind. Crop. Prod., 43: 450-456. 